which for centuries held under its spiritual sceptre the Eastern half of Christendom, which stretched from the Mediterranean shores to Manchuria, and from the Caspian Sea to the Indian Ocean. This devotion to the cause of the Nestorians, which she carried to her death-bed, began from the time when, with Professor Margoliouth, she paid a visit to their country and saw the oppressing yoke under which they lived.

Et fructus vester maneat!

A. Mingana.

\title{
Professor A. A. Bevan
}

By the death of Professor Bevan the Society loses one of its oldest members, whose profound erudition had long been prized by the inner circle of those concerned with Orientalism. He will be sadly missed at international gatherings, where, speaking both French and German perfectly, he was so often an honoured and delightful guest. It seems fitting that the Lord Almoner's Professorship of Arabic, which he held during forty years, should expire with him; no one coming after him could have given to the Chair such distinction and dignity as he did, nor was he embarrassed by the fact that the stipend was almost as nominal as the official duties attached to it. Regarding the events of his life little need be said here, and indeed there is not much to say. Except for brief periods in vacation he rarely left Cambridge : Trinity College, of which he was elected Fellow in 1890, remained his home till the end. He was also a Fellow of the British Academy. Educated at Lausanne and Strassburg, Bevan had already laid the foundations of his immense Semitic learning when in 1884 he came from Nöldeke to William Wright. Their influence appears in all his work; with the former he kept up a pretty regular correspondence covering about half a century. Although Arabic was the main subject of his studies he knew Hebrew and Syriac equally well, while his knowledge of Persian literature, especially Firdausi and Jalálu'ddín Rúmí, went 
far deeper than his modesty would allow him to admit. Apart from a Commentary on the Book of Daniel, still described by experts as a masterpiece, his most important work was done in the field of Arabian poetry, and it is very characteristic that he undertook it, not for any reasons of his own, but in order to carry out the wishes and complete the labours of friends who had passed away. His edition of the Naqa'id of Javir and Farazdaq in three large volumes (1905-1912) is a magnificent tribute of pietas to his old teacher William Wright. On the death of Sir Charles Lyall, with whom he virtually collaborated in preparing the text and translation of the Mufaddaliyyát, Bevan compiled the admirable Indexes published in the Gibb Series (1924). His critical powers were extraordinary, and he never spared himself. Other scholars may have cherished as high ideals, but few can have succeeded in living up to them so thoroughly. On one occasion he came to his colleague, E. G. Browne, looking so distressed that Browne thought some calamity must have befallen him; it turned out, however, that he had just discovered a slight metrical flaw in a single verse of his edition of the Naqá'id. I remember asking him whether he could give me the reference to a word omitted in Flügel's Concordance to the Qur'án; next day I received a note containing not only that but also a list of nearly a dozen similar mistakes, which he had entered in his own copy. The value of his contributions to Arabic lexicography is well known. These form but a small part of the material which, several years ago, he began to arrange and hoped eventually to publish as a supplement to existing dictionaries. Unfortunately the work, as he has left it, comprises less than a quarter of the Arabic alphabet. Bevan spent much time in lecturing, and those who, like the present writer, enjoyed the glaring contrast between his method and Browne's would probably agree that each in his own way made a deep and lasting impression upon them. As this notice can but hint at the personal qualities which endeared Bevan to his friends, let me conclude it with some words written 
from Egypt by a former pupil of his and mine : "His memory will always be for me a great inspiration, and his many kindnesses I shall ever remember with great gratitude. Having known him and studied with him, I feel that I have known and studied under the great scholars of the nineteenth century, from whom he learnt and whose accuracy and enthusiasm he so faithfully reflected."

\section{R. A. Nicholson.}

\section{Dr. Robert Halliday}

Born at Fauldhouse, a small village in West Lothian, on 28th March, 1864, Robert Halliday died at Maulmain, Burma, on 1st July, 1933. He had been a member of our Society since 1909. The son of a miner, he went as a very young lad into the coalpit, but continued his education in his spare time for a number of years, during which he acquired a knowledge of Greek, Latin, and Hebrew, with a view to the mission field. Having thus and otherwise qualified, he arrived in Burma as a duly accredited missionary towards the end of 1892, spent more than seventeen years in that capacity at $\mathrm{Ye}$, then twelve more at Phrapathom, Siam, and finally returned to Burma to continue his missionary work at Maulmain. In course of time he had become well versed in Burmese and Siamese and had also acquired a considerable knowledge of Pali. But his actual missionary work, both in Burma and Siam, was among the Mons, and in their language he was facile princeps. His Mon-English dictionary, published in 1922, is the only one and in later years he added many words and phrases in his own interleaved copy, which may serve some day as the nucleus of a supplement. Besides a number of contributions to the Journal of the Burma Research Society, he produced in 1917 a monograph on the Mons under the title The Talaings, edited several Mon texts and inscriptions, and translated the whole of the Old Testament into the language. In 1932 the University of Rangoon 